\title{
Tourism as a sphere of attracting investments in regional economic development: new approaches and best practices
}

\author{
Galina Bykovskaia ${ }^{1}$, Vera Frolova ${ }^{1}$, Anna Babaeva, ${ }^{1, *}$ \\ ${ }^{1}$ Voronezh State University of Engineering Technologies, 19 Revolution Avenue, 394036, Voronezh, \\ Russia
}

\begin{abstract}
The article deals with the problem of patriotic education by means of local history and younger generation familiarization with tourism and travelling. It is characterized history of the memorable places formation in Voronezh region, and described the priorities for the tourism industry development according to the requirements of the time. The results of the study are necessary for the creation of the region development programs and determination of economic growth prospects.
\end{abstract}

\section{Introduction}

«Tourism is of central importance to social, cultural and economic lives in the twentyfirst century and it is one of the most exciting and relevant phenomenon in today's times of great mobility» [1]. This quote reflects the current trend of the Russian socio-economic development strategy. Tourism is becoming one of the priority areas in scientific research. And more and more often we are talking about the need to create a comprehensive scientific understanding of the phenomenon of tourism. The dynamic development of tourism in the XXI century, the improvement of the tourism industry and infrastructure demonstrates its high importance for the economic development of the country. Russia has begun to pay great attention to the development of the tourist cluster, and not only within the framework of traditional tourist routes, such as Moscow, St. Petersburg, and cities included in the"Golden ring". The list of tourist attractions should be actively expanded. As part of this submission at the Federal level, it was approved 14 pilot economic zones of tourist type. They are so-called «comfortable» cities; one of them is Voronezh.

The tourist cluster of Voronezh and the Voronezh region is represented quite widely. It includes30 Park zones, 24 museums, 18 monuments and memorials, 52 objects of pilgrimage tourism, etc. However, Sergey Naumov, the Chairman of the Voronezh branch of small and mediumbusinesses "OPORA", participating in one of the discussions called our tourism as a "slow-moving business". At the same meeting, it was expressed another point of view considering tourism as "an ideology, not a cash cow"[2].

Meanwhile, tourism occupies the third place in the world after trade related to activity volume. Besides, there is another statistics: the tourism share in the economy of some

*Corresponding author: annabab1@yandex.ru 
countries is more than 50 percent. According to Yashalova N.N., et al., «tourism nowadays is of great importance for the development of many regions, appearing a catalyst for economic development. Regional tourism development is primarily related to the development of infrastructure and requires the attracting investments»[3].Therefore, it is necessary to think about how to make the tourism business profitable. It should be noted that we can proud of many unique places, our 7 cities are included in the list of the historical cities in Russia. The region population is over 2.3 million people. The territory of the Voronezh region is more than the area of such States as the Netherlands, Denmark, Slovakia. Our region has great opportunities.

\section{The research methodology}

The research methodology implies a problematic-historical approach to the analysis of modern economic and social content. During one of the meetings of Russian President Vladimir Putin with journalists of Russian and foreign mass media, it was identified some key priorities of international cooperation. In this regard, it was paid attention to the necessity of our historical and cultural wealth restoration within the framework of touring interstate exchange. The journalist of Lenta.ru was interested in the question whether the state goes too far supporting the Patriotic movement and if it isn't dangerous to substitute the concepts when hooliganism can be called a Patriotic act or a struggle for spirituality. The head of the country answered that «the state will support patriotism. We do not and cannot have any other spiritual bonds.... It is necessary to distinguish a common sense from any other "foam" that arises on this wave» [4].

Formation of patriotism contributes greatly to the direction of tourism development. The organization of the tourism industry in any country takes into account both economic and educational priorities. Recalling the memory of the past and the greater intention of experiencing nostalgia, both economic and political roles should be encouraged for local people to see the value of their cultural heritage and to pay more attention to its conservation. Over the past few years, it has been tested several special projects aimed at the tourism industry strengthening as a priority for Voronezh region. The birthday of the Voronezh region is considered to be June 13, 1934, when the Central Black Soil Region was divided into Voronezh and Kursk by the decision of the All-Russian Central Executive Committee. It was created a collection of the region symbolic attractions by its 80th anniversary.

Voronezh citizens are supposed to know the "memorable places" of their small motherland. There are several places in the city itself such as:

- Admiralty Square, where the Ship-Museum "GotoPredestination" is situated. It reminds people about the times of Peter I and the fact that Voronezh is the "Cradle of the Russian fleet";

- the Stone bridge (a landmark of the Black Soil Region capital), which was built in 1826 and became the first city construction made of brick;

- the monument to the Kitten from Lizyukov street, the hero of V. Zlotnikov's fairy tale;

- the Puppet Theater and the monument to White Bim, Black Ear, the hero of Gabriel Troepolsky's story.

Apart from these attractions there are a lot of sights in the suburbs: the natural, architectural and archaeological Museum-National Park «Divnogorie»; sport complex "White Well" with a fantastic natural landscape with a motton blue lake; the estate of the poet Dmitry Venevitinov, which is the only Russian noble estate of the XVIII century in the region; the Voronezh Biosphere Reserve with its deer and beavers; the Palace complex of Oldenburg in Ramon; the pearl of the Paleolithic age "Kostenki", where it is saved the settlement site of the ancient men of 20-thousand-year old; Khrenovskoy Stud Farm 
specialized in the breeding of Orlov Trotter[5]. Visiting these symbolic places in childhood, with the parents, or as a part of the school trips, should not only contribute to the formation of patriotism, but also serve as a factor in the economic growth of the Voronezh region.

\section{Discussion}

We are not afraid to say that Voronezh is one of the impressive regions of Russia related to the number of cultural and socially significant events that provide economic strengthening of the region. Among them are international Platonic festival, "Voronezh multinational" festival, "Night in Divnogorie", "Jazz province" and others. For example, in 2015, 399 thousand tourists visited Voronezh region, it is 16 thousand more than a year earlier. The market volume of the tourist services amounted to 935 million rubles, and the income of hotels reached 2.4 billion rubles. These figures have been growing for the last 4 years. Voronezh took the 12th place among the 20 most popular cities in Russia for summer travel. Moreover, «according to the Department for the entrepreneurship and consumer market development of the Voronezh region, the region has necessary potential for the development of domestic and inbound tourism and ranks 46th among theconstituent territory of the Russian Federation in this segment»[6] . Despite this, the region has not become a mecca for tourists yet.

Why is the development of such a profitable industry stalling? What are the reasons for this lag? The main of them include: firstly, the lack of event-trigger tours and vacation packages: the excursions are ordered one at a time, without joining among themselves, and the organizers of the festival work just with its participants. Secondly, the lack of local brands promotion: so, the Kitten from Lizyukov street has long had worthy competitors in Kazan and Cheboksary, which have become trademarks. Thirdly, the passivity of hotel owners, who overprice their services and they are more focused on weddings and banquets. The next reason is poor infrastructure: on the Admiralty embankment, where there are several tourist facilities, there are no modern cafes and toilets; public transport does not stop there. Besides, there is no connection between tour operators and event organizers: if an attractive tour package was suggested, the regional festival "Voronezh multinational" could gather not only on-stage performance groups, but also guests from different cities of Russia and other countries. In this regard, it is worth remembering that rural and gastronomic tourism is not practically developed in the region. As it was marked by Gburova J. and Matusikova D., «each region has its own unique character. The unique is hidden in its culture, namely in its folk traditions, traditional craft products, folklore...»[7].

Today, domestic tourism, without exaggeration, is one of the most promising sectors of the domestic economy. It should be understood that the efficiency of the industry depends not only on the attractions, but also on the quality of the infrastructure. "Tourism is an extremely complex field and in order to understand its complexity, none of its components should be left aside»[8]. Therefore, according to A. Klimentov, the Deputy of the Voronezh regional Duma, a member of the Committee of entrepreneurship and tourism, "it is important to create a kind of "attractive anchor" in the form of modern facilities that provide services of European level. They will decorate the appearance of the city. They'll bring it into accordance with the modern architectural trends, and at the same time they will ensure the growth of tax revenues to the budget, create new jobs, significantly expand the opportunities of small and medium businesses, make production more active and attract investment"[9]. Experts of various profiles will find a suitable market niche in this sphere. According to the results of numerous meetings, the tourism cluster is of great necessity to our region as it promises to bring us big benefits to the regional economy. As many researchers mark, tourism creates positive economic impacts like job opportunity, 
infrastructure development for local community, increased income and source of recreation, business initiatives and expansion, cultural development and improve education system thus assure improvement of standard of living...» [10].

\section{Results}

Many Voronezh entrepreneurs deal with the travel industry in their activities, in one way or another. But, compared to other types of business activity, local tourism is very poorly supported. In fact, we can talk more about its individual centers: out of more than 300 travel agencies, only dozen of them organize trips within the region. It is negligible in relation to the growing needs of the population. According to representatives of the regional branch of the all-Russian public organization of small and medium businesses the rate of a new cluster formation, which now includes about 10 participants, is increasing, and a dialogue between the government and business is being established. The activities of the cluster project developers seem to be completely irrelevant to the tourism industry (speaking, for example, about cooking or IT technologies). However, these areas are designed to ensure that the tourism industry will meet the requirements of the time.

A group of modern European and Metropolitan figures of culture headed by Eduard Boyakov, the stage director and the Creator of the Festival "Golden mask" carried out investigation on the problem of "Cultural environment and politics of the Voronezh region" in 2013. Within the framework of this event, Terry Sandell, the famous British culture expert of the UNESCO National Commission, visited Voronezh. According to his opinion, there are five key factors in the world that influence on cultural policy: unrestricted access to communications, unpredictable globalization, mobility of all kinds and forms, virtual access to everything, digitalization. English scientist noticed that today culture is not viewed as a spectrum in Russia in General and in Voronezh in particular. As a result, there are two weaknesses of our cultural policy: static, narrow definition of the concepts of "culture" (this is what the Ministry of culture does) and disregard of "subcultures" existence in society. "Cultural policy in the modern world can not accept these changes, otherwise it becomes marginal," - said the Mr. Sandell [11].

Therefore, the work aimed at Voronezh region archaeological heritage preservation is being activated now by the Public Council. It has been recorded that 2693 archaeological, historical and cultural complexes and monuments of Federal and regional significance are located in Voronezh. Moreover, 1540 newly discovered objects have been registered recently. They are our cultural heritage.

\section{Conclusion}

In June 2015, a video conference "Tourism in the Voronezh region" took place in the Black Soil Region capital within the framework of the "Portal of the business climate improvement in Voronezh region". During the event, the representatives of the business community and the government discussed the prospects of this industry development in our region.

The main tourist clusters were identified. The tasks can be presented as a table.

Table 1. Projects of tourist clusters of the Voronezh region implemented in 2016-2021 [12].

\begin{tabular}{|c|c|}
\hline Project title & Project implementation results \\
\hline $\begin{array}{l}\text { The Palace complex of } \\
\text { Oldenburg }\end{array}$ & $\begin{array}{l}\text { Restoration of the Palace and Park area, construction of a } \\
\text { hotel and restaurant }\end{array}$ \\
\hline $\begin{array}{l}\text { "Dendro-Safari Park in } \\
\text { Voronezh» }\end{array}$ & $\begin{array}{l}\text { creation of a Park zone and a contact zoo, construction of a } \\
\text { hotel, restaurant and children's cafe }\end{array}$ \\
\hline
\end{tabular}




\begin{tabular}{|l|l|}
\hline $\begin{array}{l}\text { tourist and recreational complex " } \\
\text { Horseradish stud farm» }\end{array}$ & $\begin{array}{l}\text { Creating a Park zone, equestrian sections, and a contact } \\
\text { zoo. }\end{array}$ \\
\hline $\begin{array}{l}\text { Educational and excursion } \\
\text { program " Academy of dairy } \\
\text { Sciences» }\end{array}$ & $\begin{array}{l}\text { At Ekonivaagro enterprises, excursion programs are } \\
\text { created where students are introduced to the process of } \\
\text { producing dairy products from cow rearing to packaging. }\end{array}$ \\
\hline $\begin{array}{l}\text { ethnographic complex " Village } \\
\text { of the XVII-XIX centuries», }\end{array}$ & The creation of the ethno-Park zone \\
\hline $\begin{array}{l}\text { interactive children's center "Life } \\
\text { behind glass" in the Grafsky } \\
\text { nature reserve }\end{array}$ & $\begin{array}{l}\text { Excursion programs for children and teenagers that allow } \\
\text { real-time observation of the life of beavers in the huts, } \\
\text { including under water. }\end{array}$ \\
\hline
\end{tabular}

In addition, the conducted sociological survey of residents of the city and region showed that the main interest is observed in the objects of agrotourism

Table 2. Results of voting for identification leading attractions of the Voronezh region [12].

\begin{tabular}{|c|c|}
\hline Item & $\begin{array}{c}\text { Those who voted for it (as a } \\
\text { percentage of the total number) }\end{array}$ \\
\hline Khoperskystatereserve & 9.33 \\
\hline Loma nature and landscape Park & 9.33 \\
\hline KalacheevskiyCretaceouscave & 5 \\
\hline «VoronezhChernozem» & 4.5 \\
\hline DivnogoryeEco-Complex & 3.17 \\
\hline
\end{tabular}

Black Soil Region has many tourist attractions; however, the travel industry is experiencing difficult times. Among the main reasons is the fact that the majority of the entrepreneurs consider this industry as a way of earning, forgetting about the spiritual component of this business, and the necessity of the Patriotic feelings formation during travel. Other reasons for the poor development of tourism include uneven load of tourist locations and incompetence of tour guides and travel agents. As it was noticed, «retention of the tourism industry current position ... will lead to the stagnation of the regional tourist market of the Voronezh region and contribute to the loss of competitive advantages in the tourism sector...».[13]

Meanwhile, Voronezh region has all chances to become attractive for tourists.It should be remembered that «for a Nation as a whole, a chance of development on a global scale starts from the local one»[14].

Voronezh science gave the world many names and discoveries. Among the most famous scientists, reflected glory on the region, are such bright personalities as: Nikolai Burdenko (the outstanding surgeon, the founder of neurosurgery), Konstantin Glinka (soil scientist, the founder of paleopedology, the first rector of Voronezh State Agricultural Institute ), Nikolai Basov (Noble prize winner, the founder of Quantum Radiophysics), AvediktMazlumov (sugar beet breeder), GeorgyMorozov (one of the founders of the scientific forestry), Nikolai Severtsov (the founder of Russian ornithology and zoogeography), Pavel Cherenkov (Nobel prize winner for "Cherenkov effect"). Visiting the places where only these scientists worked, lived and created scientific works can already make up several tourist routes. It is not by accident, a Square of Science and Scientists has appeared near Voronezh State University recently.

\section{Recommendation}

In 2014, when Voronezh region was 80 years old, the project "Seven wonders of Voronezh region" was developed. People of the region were suggested to choose seven key attractions, which will become the landmark of the region. The choice was to be made from 
94 natural, architectural, cultural, historical and geographical objects. The majority of inhabitants voted for the Khoper Nature Reserve, Natural Landscape Park "Lomy", Kalach Chalk Cave, Voronezh black soil (the famous research Institute "Stonesteppe", created by V. V. Dokuchaev, has survived to the present days), Museum National Park "Divnogorie", Alexander NevskySpeos, Shipov's forest. According to the idea of the organizers, projects of this kind arouse great interest to history and culture, as well as help to determine the topics on which booklets and guide books are in demand.

Together with Moscow and Kazan, Voronezh is in the top of 10 destinations for family holidays. The rating was developed by the analysts of the portal, specializing in online booking. At the same time, the capital of Black Soil Region welcomes guests with more affordable prices. As the survey showed, tourists with children visit monument to the Kitten from Lizyukovstreet, ship "GotoPredestination", as well as Biosphere Reserve in Grafskaya, Khrenovskoy stud, castle in Ramon and the children's Park "Orlyonok" in the city of Voronezh.

It is especially important for the development of tourism business to improve the city airport work. Its reconstruction has been carried out for several years. Currently, the air strip, taxi track, lighting facilities have been updated. The station square has been transformed. All this has increased the capacity of the air harbor. But, it is not enough as about 400 thousand tourists, including foreign ones, come to Voronezh region every year.

The airport will be named after Peter the Great and it's not an accident. The personality of Emperor Peter I - as an option - can become an "anchor" figure of Voronezh tourism. The Church of the time, when Peter I created Fleet here, contains memorials devoted to the Russian sailors memory, and the relics of Fyodor Ushakov, the great naval commander. Next to the Assumption Church there is a battleship "GotoPredestination". The iconic ship, created by Emperor, is considered to be a symbol of Peter's reforms. There are some places on the territory of the region that Peter loved and visited, for example, the church in Divnogorie. In addition, we can suggest a number of the same iconic names, in particular poets A. Koltsov, I. Nikitin, I. Bunin, S. Marshak.

But to promote the excursion potential of the region, in addition to interesting places and historical rarities, it's necessary to have an information center involved in the work of regional recreational opportunities application; to develop a system of training guides; to arrange a network of souvenir shops, to prepare some educational guide books, brochures and interesting publications on the history of the region[15].

Local tourism, in contrast to world's tourist centers visiting, is becoming more popular in Russia, due to the sanctions applied to our country by a number of foreign states. Such initiatives as the establishment of the Federal Program for the development of tourism and grants, and creation of tourism clusters have given the first positive results. According to "Rosturizm", the industry has increased by $18 \%$, and the number of Russians choosing domestic routes reached 50 millions. In other words, domestic tourism is one of the points of our region economic growth, so it is reasonable and appropriate that the regional administration has taken decision on tourism projects grant financing from the regional budget.

\section{References}

1. N. Kozak, M. Kozak, Tourism research: an interdisciplinary perspective (Scholars Publishing, Cambridge UK, 2013)

2. A. Pavlov, Communa (Voronezh, 2018) 
3. N.N. Yashalova, M.A. Akimova, D.A. Ruban, S.V. Bojko, A.V. Usova, E.R. Mustafaeva, Economic and social changes: facts, trends, forecast 10(2), 195-213 DOI: 10.15838/esc/(2017).2.50

4. T. Gashimova, Communa (Voronezh, 2016)

5. E. Shedogubova, Love at first sight (Chizhov Gallery, Voronezh, 2016)

6. T.M. Khudyakova, A.S. Ryazancev, Bulletin of Tambov State University 2, 727 (2013)

7. J. Gburova, D. Matusikova, Economic Annals-XXI 9-10(1), 102-105 (2014) http://soskin.info/userfiles/file/2014/9-10_2014/1/Gburova,Matusikova.pdf

8. F.A. Herle, Marketing from Information to Decision Journal 1(2), 14-26 (2015)

9. A. Klimentov, Tourism has two sides (Chizhov Gallery, Voronezh, 2015)

10. D. Kreag, The Impacts of Tourism. Minnesota Sea Grant Program, http://www.seagrant.umn.edu/tourism/pdfs/ImpactsTourism.pdf.

11. G. Wall, A. Mathieson, Tourism: Change, Impacts and Opportunities (Prentice Hall, England, 2016)

12. Voronezh statistical Yearbook 2019: Stat. sat. (Voronezh, 2019)

13. C. Webster, S. Ivanov, Tourism Management 40(1), 137- 140 (2014)

14. A. Kostin, Metro: Voronezh and the whole world 3 (2013)

15. G.A. Bykovskaya, Spiritual life of Russian regional communities: history, traditions, modernity (Kazan, 2015) 